\title{
TEXTO E ILUSTRACIÓN EN EL LIBRO MEDIEVAL: FACTURA FÍSICA, LECTURA Y RECEPCIÓN
}

\author{
Marta Haro Cortés \\ Universitat de València \\ marta.haro@uv.es
}

El libro medieval consolida un fecundo y fascinante diálogo - no por ello menos complejo- entre texto e ilustración. Letra y figura -iniciales historiadas, caligramas y otros muchos y variados motivos decorativos-, escritura e ilustración -miniaturas y grabados- convivirán a lo largo de los siglos en un novedoso soporte que impondrá la página (el bifolio) como modelo de lectura y de diseño gráfico e icónico (impaginación).

La relación entre texto e imagen en la producción libraria de la Edad Media es un ámbito de estudio interdisciplinar y ese ha sido el punto de partida metodológico del presente monográfico que recorre, a lo largo de sus páginas, un amplio abanico de investigaciones que atienden al proyecto iconográfico y planificación del libro, en relación con el género o modalidad literarios y con sus sistemas ornamentales fijados por la tradición iconográfica; así como a la lectura de la imagen en relación con el texto y viceversa, analizando la coherencia y correspondencia entre texto e ilustración que se establece entre ellos, su contexto histórico-social, su dimensión ideológica y las transformaciones a través del tiempo, para delimitar la finalidad del aparato icónico $\mathrm{y}$, según esto, ahondar tanto en el comitente, como en el receptor y, de ahí, en las estrategias de lectura -incluso en diferentes periodos--. Sin pasar por alto que la factura física del ejemplar y su valía material y artística vendrán determinados por los intereses y expectativas del emisor del encargo y por la entidad del destinatario y, en este sentido, el coste del producto final dependerá de la pericia y calidad de los profesionales y artistas que intervengan en el proceso de elaboración ya sea manuscrito o impreso. 
El vínculo entre la palabra y la ilustración se formaliza en función del receptor y no solo orienta, clarifica, interpreta, amplifica y enriquece la lectura, sino que también favorece la aprehensión y memorización del contenido y, no menos relevante, cumple una función estética. El discurso del texto y el discurso de la imagen son comunicaciones autónomas proclives a enlazarse, fundirse, complementarse, subyugarse, absorberse la una a la otra, mantenerse independientes, confundirse, explicarse, traducirse, ornarse; pero, en definitiva, sea cual sea la entidad y extensión de esa correlación, confluyen en el libro ilustrado.

No cabe duda de que uno de los capítulos fundamentales y primigenios en la historia de la miniatura es la ilustración de la Biblia: la imagen como instrumento de enseñanza de las Sagradas Escrituras y de comprensión del mensaje doctrinal de letrados y analfabetos (litteratura laicorum, como ratificó Gregorio Magno). Asimismo, en el ámbito de la exégesis bíblica, el Apocalipsis de san Juan gozará de enorme interés y proliferarán sus comentarios. La relación entre texto e iconografías bíblica y apocalíptica, su evolución, transmisión y recepción son el objeto de estudio, respectivamente, de los artículos de Gemma Avenoza, «Imagen y texto en manuscritos bíblicos hispánicos» y de Elisa Ruiz, «Imagen como texto, texto como imagen».

Gemma Avenoza, a partir de cuatro manuscritos bíblicos -los escurialenses I-I-4, I-I-7, I-I-5 y la Biblia de Arragel o Biblia de Alba-, estudiará el diálogo entre texto e imagen, centrándose en las expectativas de los comitentes de dichos ejemplares, ya que, de acuerdo con los argumentos de la autora, las miniaturas, más allá de la exigencia artística, sirven «de expresión iconográfica a un pensamiento que no se expresa con palabras nacido del entorno en el que se produjo la copia e iluminación del manuscrito». El corpus seleccionado presenta programas iconográficos complejos y, además, todos ellos son códices castellanos de traducciones bíblicas del hebreo, realizadas en el siglo XV, en pergamino y encargados por importantes nobles cristianos. En todos los testimonios, las expectativas de quien realiza el encargo condicionan el proceso de copia e iluminación y la relación entre texto e imagen, ya que hay un claro deseo por vincular la obra al comitente. La Biblia de Arragel, encargada por el Gran Maestre de Calatrava, presenta más de 320 miniaturas que están al servicio de la comprensión del texto bíblico y de su comentario, hasta tal punto que las glosas, en algunos casos, cambian su orden para que la relación entre texto e imagen sea compacta y así cumplir con el deseo de D. Luis de Guzmán. En el manuscrito escurialense I-I-4, las tres series de miniaturas funcionan como complemento visual y comentario gráfico del texto y se trata de historias significativas de la historia de Israel 
(primera serie), «o una crítica de costumbres que se entendían como desviadas sumada a una dilatada discusión exegética» (las otras dos series). En I-I-7 se conservan 4 miniaturas que ilustran únicamente el Génesis y el Éxodo; quizá, a juicio de la estudiosa, la selección de las imágenes esté relacionada con los modelos conceptuales icónicos transmitidos por las Haggadot, más que con los de la biblia cristiana. Por último, en el proyecto iconográfico del manuscrito escurialense I-I-5 hay un claro propósito por subrayar la ortodoxia cristiana y también el interés del poseedor por la historia de Job y sus catástrofes, ilustrando así uno de los temas más fructíferos de la Edad Media: la fortuna mudable y la ineludible resignación. Por tanto, en todos los códices analizados, la relación texto-imagen proyecta el vínculo entre los deseos, expectativas e intereses del destinatario y la labor de los copistas e iluminadores.

Elisa Ruiz, por su parte, traza la trayectoria y evolución del capítulo XII, 1-17 del Apocalipsis, que narra la visión intelectual que acontece a Juan; episodio que, dada su ambigua interpretación, ha sido profusamente comentado e ilustrado a lo largo de la historia. La imagen facilita y simplifica la comprensión intelectual del mensaje abstracto, por tanto, la representación icónica debe considerarse como «un código semántico metadiscursivo para el lector». El estema del ciclo hispano del Apocalipsis, elaborado a partir del exitoso Comentario atribuido al Beato de Liébana, permite distinguir 17 manuscritos que ilustran la Historia Draconis et Mulieris; la estudiosa centrará su atención en los nueve testimonios (siglos x al XIII) más significativos por su originalidad en cuanto a la fantasía creativa del aparato icónico, para dar cuenta de las modificaciones que los distintos iluminadores, de acuerdo con los estilos de cada época, han ido introduciendo $y$, de este modo, reconstruir la filiación de los manuscritos. El estudio comparativo de la relación texto e imagen de los ejemplares deja clara constancia de que el proceso icónico fue objeto de continua redefinición, frente a la invariabilidad textual del fragmento del Apocalipsis. Asimismo, su recepción entre clérigos y laicos como libro de estudio o lectura «habría contribuido a la progresiva conformación de tres componentes, texto, imagen y comentario por razones hermenéuticas». La siguiente escala es el ciclo anglo-francés del Apocalipsis, en concreto, Elisa Ruiz analiza el ms. Fr. 403 de la Biblioteca Nacional de Francia y demuestra que el tratamiento individualizado de imágenes para glosar un episodio favoreció la creación de modelos iconográficos autónomos de larga difusión, que progresivamente fueron perdiendo su relación con el texto fuente, de modo que «si en los primeros testimonios aquí descritos la imagen equivalía al texto, a partir de la Modernidad el texto depende de la imagen». 
La producción de libros iluminados patrocinados, encargados o dedicados a la realeza y a las altas jerarquías nobiliarias y eclesiásticas es otra de las secciones temáticas de este monográfico. Marta Haro Cortés, en «Semblanza iconográfica de la realeza sapiencial de Alfonso X: las miniaturas liminares de los códices regios», traza la evolución del modelo iconográfico del rey sabio que el propio monarca consolida en las exquisitas ilustraciones, de su producción libraria. El punto de partida para llevar a cabo el análisis es la cronología de la elaboración material de los ejemplares del taller alfonsí que presentan imágenes del rey, todos ellos realizados en la última década de su reinado. La primera escala son las compilaciones científicas, en ellas Alfonso $\mathrm{X}$ aparece en el cuerpo de una capital; estas ilustraciones, más que de presentación del códice terminado a su comitente, son miniaturas proemiales que concretan el mecenazgo traductor y compilador del monarca. Por lo que respecta a las Estorias, estamos ante imágenes de legitimación y transmisión del poder, ya que retratan el ceremonial monárquico y se revisten de significado político, son la más nítida representación salomónica de Alfonso X y de su arquetipo político de realeza sapiencial. Las Cantigas, sin embargo, estampan todo el proceso de creación intelectual y material del cancionero mariano, siendo la imagen del rey con el libro el centro privilegiado de dichas miniaturas. Por último, las imágenes liminares del Libro del ajedrez, dados y tablas son las únicas en las que el rey no contempla o porta el ejemplar del libro, pero su simbología es subsumida por el emblema de la labor de traducción y creación intelectual y física de todos los proyectos librarios regios, el taller alfonsí, que aparece en una de sus miniaturas. La autora considera que el motivo icónico privilegiado en las imágenes liminares de representación personal de Alfonso X es el rey con el libro que presenta distintas variantes relacionadas tanto con el género literario y visual, como con la amplia gama de atribuciones que conforman el concepto de autoría alfonsí y, al mismo tiempo, consolidan el modelo iconográfico de la realeza sapiencial que el rey sabio personifica encumbrando el saber, simbolizado por el libro, a la categoría de regalia.

La contribución de David Nogales Rincón se centra en historiografía, en concreto, «La Genealogía de los reyes de España de Alonso de Cartagena: linaje e imagen regia en la Castilla del cuatrocientos», dedicada a la recepción de este sumario de crónicas del obispo de Burgos, a partir del estudio del programa iconográfico de sus diferentes testimonios. La incorporación de la ilustración a la Genealogía está estrechamente relacionada con la memoria rerum, esto es, la memorización de los temas principales del texto, cada uno de ellos asociado a una imagen sumaria; así como también con la brevedad, 
ya que la imagen es un instrumento de síntesis nemotécnica. Uno de los aspectos más originales del programa iconográfico es que sus indicaciones están incluidas en el cuerpo del texto y parecen dirigidas no solo al profesional, sino también al lector, «así, dichas indicaciones ofrecerían a este último las claves iconográficas para interpretar la imagen que estaba contemplando y, a su vez, le permitirían reforzar la memoria artificial, a través de la imagen mental creada a partir de la lectura de las indicaciones iconográficas». Los testimonios más antiguos de la obra presentan el espacio reservado para las imágenes, siguiendo una disposición texto-imagen más cercana a las crónicas ilustradas que a las genealogías; aunque las ilustraciones no se llevaron a cabo, estas con toda probabilidad inaugurarían cada una de las semblanzas. En la segunda parte del trabajo, el estudioso analiza los cuatro testimonios de la Genealogía que desarrollan el programa iconográfico diseñado por Cartagena: A (Archivo Histórico Nacional, Códices y Cartularios, 983), P (Real Biblioteca, II/30009), E1 (Biblioteca de El Monasterio de El Escorial, h.II.22) y N ${ }^{4}$ (Biblioteca Nacional de España, Vitr. 19/2). Y que dejan constancia de los dos ámbitos de recepción principales en los años inmediatos a la composición de la obra: el entorno del difunto obispo de Burgos y la corte real de Enrique IV. Si bien en el primer caso el interés sería ante todo intelectual en el marco historiográfico; en el segundo, podría estar relacionado con la propaganda y legitimación real «en un contexto marcado por el enfrentamiento del rey con parte de la nobleza del reino, que culminaría en 1465 con la proclamación como rey de Alfonso XII de Castilla (1465-1468)».

La ilustración de la literatura venatoria medieval es el ámbito de estudio de José Manuel Fradejas Rueda en «Iluminar la caza en la Edad Media: aproximación a la iconografía venatoria medieval iberorrománica». El autor sienta las bases de su estudio y explicita la pobreza de imágenes de los textos venatorios hispánicos, a su juicio, debido a que «son textos prácticos, realmente copiados para los cazadores, no para guardarlos en las bibliotecas de los grandes señores». Hace referencia a las noticias conocidas sobre el Libro de las cacerías del Rey don Pedro I, que es reseñado como códice precioso con casi 200 iluminaciones, pero en paradero desconocido; se centra en el Libro de la montería que es, en cuanto a decoración, el más rico conservado, aunque de las 14 miniaturas solo se realizaron 6 , y nos ofrece un exhaustivo análisis de las mismas. Cercano a este códice, fija su atención seguidamente en la copia del Libro de la montería de la Biblioteca Nacional de Francia, ms. espagnol 286 -solo contiene los dos primeros libros de los tres que forman el tratado- y describe sus decoraciones marginales en las que proliferan dragones y seres fantásticos e, incluso, algunos animales que no tienen nada 
que ver con la materia de la obra, pero, con todo, también presenta detalles monteros. En definitiva, «un manuscrito ricamente decorado que a duras penas se puede considerar un manuscrito de caza iluminado». Para completar el canon montero iberorrománico pasa revista al Tratado de montería, que no está miniado, y al Livro da monteria de João I que solo presenta dos esquemas. Los textos cetreros son analizados en la segunda parte de su trabajo y «la iluminación que presentan, como se ha avanzado, son los instrumentos quirúrgicos». El Livro de falcoaria de Pero Menino, difundido gracias al Libro de la caza de las aves de Pero López de Ayala y sus epígonos: Juan de Sahagún y Juan Vallés, estampa en imágenes el primer botiquín del cetrero, más completo en ilustraciones en la obra de López de Ayala. La última parte se centra en las miniaturas que representan escenas tópicas de caza (Cantigas de Santa María, Libro del caballero Zifar, o libros de horas de Isabel la Católica o Juana la Loca).

La imagen convertida en palabra, esto es, el campo de acción de la écfrasis, es desarrollado por Barry Taylor en su artículo «La écfrasis en el siglo Xv: maravilla, metatexto y alegoría». Pese a que los manuales retóricos clásicos reconocen la evidentia, pero no señalan el término «écfrasis», es manifiesto que se componían écfrases y que se seguían «modelos y no preceptos». En este sentido, tanto la prosopopeya como la topotesia están relacionadas con la écfrasis y el estudioso establece sus vínculos en el primer apartado de su trabajo. La siguiente escala de análisis son los textos medievales no hispánicos que presentan écfrases como las canciones de gesta francesas, el Roman d'Alexandre -que reúne un mapamundi, los doce meses, la historia de Elena y de Hércules, las horas y los días y también los planetas-; el Anticlaudianus de Alano de Lille-Virtudes y Ciencias personificadas, así como retratos de figuras ejemplares o la Casa de Fortuna, que tanta influencia ejerció en otros autores medievales-; el Roman de la Rose -con sus personificaciones o la topotesia del jardín de Placer-; la Mutacion de Fortune de Christine de Pizan -con la descripción del Castillo de Fortuna y las pinturas que adornan su exterior-y la Hypnerotomachia Poliphili de Francesco Colonna -en la que se detallan objetos plásticos de todo tipo, como templos, carros, obeliscos o estatuas-. Barry Taylor considera que la écfrasis está relacionada principalmente con géneros como la épica y el sueño-visión alegórico, si bien en algunos casos «es un simple elemento decorativo o digresión, en otros funciona como un metatexto que es la clave de toda la obra» $\mathrm{y}$, además, no solo proyecta la maravilla, sino que también depara una visión privilegiada y, paradójicamente, no alude a las pinturas. En lo que respecta a los textos castellanos medievales, última parte de su trabajo, se ocupa pormenorizadamente del Libro de Alexandre -único ejemplo de écfrasis 
anterior al siglo Xv-, del Laberinto de Fortuna de Juan de Mena, de la Visión deleitable de Alfonso de la Torre, del decir «Oyd maravillas del siglo presente» de Pero Guillén de Segovia, del Triunfo del Marqués de Santillana de Diego de Burgos y también hace referencia a la relativa ausencia de écfrasis y topotesia en el sueño-visión amoroso y su progresiva decadencia en el ámbito del román.

Hugo O. Bizzarri, por su parte, examina el texto gráfico convertido en figura, en concreto, el caso de los diagramas, en su trabajo "Las 'figuras' de Poridat de las poridades». Dos pasajes de esta conocida obra «aluden a 'figuras' con el sentido de ilustración». El primero de ellos, final del capítulo III, dedicado a la justicia, es «un diagrama octogonal, con el cual en la literatura sasánida se justificaba la armonía del reino» y en Poridat dicho diagrama compara el reino con un huerto, pero en ninguno de los ejemplares de la obra se ha conservado este gráfico. Sin embargo, dos testimonios: el manuscrito $\mathrm{L}$, al final del capítulo 8 dedicado al lapidario (ms. iluminado $\mathrm{n}^{\circ} 46$, de la Biblioteca Nacional de Lisboa) y el N, capítulo 7, al final del conocido «cuento de los caballeros que van a lidiar» (escurialense h.III.1), recogen un diagrama que explicita el modo de utilizar el cuadrante para triunfar en la batalla, sacando a los caballeros en número descendiente; por tanto, prima un criterio de elección numérico. El estudioso da cuenta de la tradición de este diagrama y se detiene en uno de los interrogantes fundamentales de la tradición de Poridat de las poridades: si en su origen fue un libro ilustrado.

La llegada de la imprenta supone, sin duda, uno de los cambios tecnológicos más relevantes en la cultura occidental que da respuesta, mediante la copia mecánica, a una demanda cada vez mayor de lectura y convierte el libro en un producto comercial y cultural. La relación entre texto e imagen en incunables e impresos es otra de las secciones de este volumen, que se extiende, más allá del ámbito técnico y de composición, al contexto social, cultural, ideológico e, incluso económico, que motiva la edición, a los agentes que participan en el proceso editorial, a las relaciones entre impresores -tanto de sus materiales tipográficos, como de negocios comunes-, a las distintas ediciones realizadas en diversos talleres, su difusión y recepción, así como a los géneros literarios y editoriales.

Juan Manuel Cacho Blecua en «Texto e imagen en la Estoria del noble Vespasiano (Sevilla, 1499): la curación del emperador», aborda el estudio de las 15 xilografías que ornan la Estoria del noble Vespasiano que vio la luz en Sevilla, en el taller de Pedro Brun en 1499, y la relación de las mismas con el texto y su contexto. Las estampas de la edición de Lisboa (1496) y las de Sevilla (1499) se remontarían a idénticos modelos, aunque se diferencian en multitud de detalles que serán exhaustivamente expuestos. Por lo que 
respecta al incunable hispalense, sus ilustraciones han sido creadas para esta obra y se han ubicado en los episodios más significativos, el resultado es un libro breve «de cierto lujo». A juicio de Cacho Blecua «las viñetas no tratan de transcodificar los signos verbales a otros gráficos de modo exacto, sino de reflejar situaciones significativas, memorables, como también lo atestiguan ciertos desajustes entre las palabras y sus grabados». Gran parte de las imágenes se centran en la aniquilación de Jerusalén y el castigo a los judíos y en escenas bélico-caballerescas; mientras que el castigo a Pilatos solo se estampa en un único grabado, al igual que la salvación milagrosa de Job. El viaje de Gais para hallar remedio para Vespasiano y el bautismo de este es el otro gran eje de contenido que presenta más ilustraciones y en las que el estudioso se detiene con mayor atención para establecer sus relaciones. En primer lugar, se analizan los «desplazamientos marítimos» que van más allá de su aparente condición preliminar, ya que proyectan un desplazamiento político-religioso hacia la Roma imperial, por un lado, y hacia la Roma cristiana, por otro. El siguiente núcleo es el de la «curación de Vespasiano: Verónica y la Santa Faz» en el que se plasma, a través de las imágenes, que la lepra física y espiritual se cura con la fe en Cristo, mensaje también dirigido por las autoridades hacia los hebreos hispanos. El último apartado es el relativo a «la construcción de la Iglesia: la custodia de la Santa Faz» en el que se explicita cómo realidad y ficción se interrelacionan, y así los grabados de esta sección adquieren total sentido en contraposición con otras imágenes de la destrucción de Jerusalén. Por tanto, el aparato icónico de la Estoria del noble Vespasiano no solo refuerza determinadas tesis político-religiosas que recobran actualidad, sino que también potencia el sentimiento religioso y la devotio moderna.

El análisis del material gráfico del primer incunable del Libro del Anticristo de Martín Martínez de Ampiés es estudiado por María Jesús Lacarra en «El ciclo de imágenes del Libro del Anticristo [Zaragoza: Pablo Hurus, 1496]». La obra es un compendio de varios textos de temática afín, unos compuestos por el hidalgo aragonés y otros, traducidos. La autora centrará su atención en las imágenes del Libro del Anticristo - primera obra del conjunto y la que más xilografías presenta-, identificará sus modelos iconográficos y, asimismo, analizará su correspondencia textual. El incunable salido del taller de los hermanos Hurus - que se conserva en un ejemplar en la Biblioteca Pública de Nueva York- cuenta con 64 grabados, algunos de ellos repetidos, de los cuales 46 son escenas de la vida del Anticristo, siguiendo el De ortu et tempore Antichristi de Adso de Montier. De estas 46 xilografías, 36 proceden de Estrasburgo y habían sido creadas específicamente para ilustrar el Antichrist alemán, en total 34 tacos (ya que dos están repetidos); para más detalles, 
apunta la estudiosa que en el incunable español, para disimular las imperfecciones, los grabados aparecen rodeados de un marco decorativo floral. La diferente relación texto-imagen que se observa entre el impreso alemán y el incunable de los Hurus es analizado con todo detalle, para centrarse después en los 8 tacos nuevos que ilustran la obra y que, claramente, han sido tallados por otro profesional que traza composiciones más complejas. A juicio de María Jesús Lacarra, estos tacos fueron creados para esta edición; de ahí que el resultado de la intervención de varios artistas lleve consigo modificaciones y cambios en el discurso visual «que podemos concretar en dos: una acentuación del contenido antisemita y una diferente representación de la figura del Anticristo y de los diablos que le acompañan». La procedencia diversa de las imágenes y la adaptación de la obra a un nuevo contexto proporcionan una lectura diferente: del ámbito de recepción popular del Anticristo alemán, al texto erudito y grave de Martín Martínez de Ampiés.

Josep Lluís Martos en «Un incunable de Pere Trincher: tipografía, decoración y datación», determina la fecha de impresión de Obra a llaors del benaventurat lo senyor sant Chirstòfol, fruto de un certamen literario celebrado el 31 de agosto de 1488 y publicado en Valencia, de acuerdo con el colofón del ejemplar, el 3 de febrero de 1498. El lapso de tiempo entre la celebración del acto y la publicación de la obra es el principal problema de este cancionero que será resuelto en este trabajo, a partir de un exhaustivo análisis de la morfología y sintaxis de las capitulares góticas del impreso. Todas las capitulares son grabados xilográficos -diez en total (cuatro letras: la $L$ repetida en cinco ocasiones, la $S$, en tres; la $P$ y la $A$ ) - con rasgos diferentes. Esta peculiaridad permite a Martos pensar «en la hipótesis de una procedencia diferente de los tacos, que, respondería, en última instancia, a una voluntad improvisada de ennoblecer un impreso [...] elaborado por un librero metido a tipógrafo». Por otro lado, las capitulares están alineadas con la caja de escritura por la parte superior y por el margen izquierdo, si bien es característica su falta de sistematicidad y, sobre todo, la inclinación de algunas de estas iniciales que podría deberse a que no fueron estampadas al mismo tiempo que el texto y, además, es evidente que la calidad del estampado disminuye según avanza la impresión «que parece justificarse por la diferencia de material entre las matrices de madera de las capitulares y el metal de los tipos». Con todo, el uso de las capitulares se caracteriza por su fusión armónica con el resto del texto en color y formato, característica que responde, como demuestra y desarrolla el estudioso, a una función tipográfica relacionada con la estructuración del impreso y con la organización textual. La importancia de este incunable de Pere Trincher reside «por un 
lado, en que es el primer impreso valenciano que conservamos con matrices xilográficas y, por el otro, en que la heterodoxia morfológica de sus diseños esconde, en realidad, las primeras manifestaciones de diferentes estilos de iniciales ornadas». Es por ello que Martos considera que debió ser Trincher el introductor de dichas matrices en la imprenta valenciana. La parte final del estudio se centra en la relación entre Pere Trincher y Lope de la Roca como impresores de los proyectos editoriales de Miquel Albert, siendo este último el que adquirió los tipos, matrices y planchas de Trincher en 1495. Todas las argumentaciones expuestas en este trabajo permiten confirmar que la Obra a llaors del benaventurat lo senyor sant Chirstòfol fue impresa por Trincher el 3 de febrero de 1489, "con lo que estamos ante las primeras capitulares en madera y ante las primeras ilustraciones mediante grabado de la imprenta incunable valenciana».

Los motivos iconográficos de la ficción sentimental son abordados por Carmen Parrilla en «Vestir las palabras: grabados xilográficos en la ficción sentimental». En primer lugar, la autora se detiene en las portadas de la Historia de Grisel y Mirabella, tanto en la edición de Juan Varela de Salamanca de 1514, como en las ediciones sevillanas de Cromberger (1524, 1526, 1529, 1533), o la edición de Toledo de 1526, entre otras, y queda evidenciado cómo adquiere protagonismo la contienda entre Torroella y Braçaida, frente a la narración trágica de los amantes. Por lo que respecta al Tractado de Arnalte y Lucenda de Diego de San Pedro, las dos ediciones conocidas emplean en sus frontispicios motivos diferentes, la de Burgos de Fadrique Alemán de 1491, el motivo del enamoramiento de los jóvenes y en la de 1522 de su yerno Alonso de Melgar, un joven entregando una flor con un mensaje a una dama. Sin embargo, en la Cárcel de amor las imágenes que acompañan su fecunda difusión, por lo general, están bien adaptadas a las circunstancias narrativas de la obra. Se presta especial atención y análisis a las ediciones de Hurus de 1493; Rosenbach, 1493; la de Burgos, Fadrique Biel, de 1496 y la de Jorge Coci de 1523. Para Carmen Parrilla es notable el contraste entre las ediciones anteriores y la de Jorge Coci: «estos grabados de Coci carecen del aparato arquitectónico, ornamental y decorativo que habían proporcionado las anteriores impresiones de la Cárcel [...] en las que, con magnificencia y detallismo se encuadraban preferentemente las escenas narrativas de interiores». Y, asimismo, los grabados de esta edición que acompañan la sección dramática de la obra - a partir de la prisión de Laureola- revisten mayor originalidad y detallismo. En suma, potencian el sentido y la expresión del mensaje literario y, señala la estudiosa, que el programa de imágenes de Coci no se aparta del sistema narrativo-pictórico desarrollado por los impresores anteriores. 
Concluye el apartado dedicado a la Cárcel de amor con su impresión veneciana de 1531. Y pone punto final a su trabajo con la portada de la Cuestión de amor impresa en Valencia por Diego Gumiel en 1513.

La producción ilustrada del impresor Fadrique Biel es el objeto de estudio de José Luis Canet en «Reflexiones sobre el libro ilustrado del impresor Fadrique Biel de Basilea». El autor va analizando los grabados utilizados por el impresor afincado en Burgos, desde 1493 hasta 1499-1502, en obras como el Repertorio de los tiempos de Andres de Li (1493), concretamente, la parte segunda relativa al Lunarium de Bernardo de Granollachs; la Cárcel de amor de Diego de San Pedro (1496), El libro del Ysopo, famoso fablador, historiado en romançe (1496), el Libro del Anticristo (1497), el Exemplario contra los engaños y peligros del mundo (1498), La historia de los nobles cavalleros Oliveros de Castilla y Artús de Algarbe (1499) y, por último, una serie de obras de las que no se conoce con certeza la fecha de impresión, pero que estarían en el periodo comprendido entre 1499 y 1502: Stultifera naves de Badius Ascensius (¿1500?) y los grabados de la Comedia de Calisto y Melibea (¿1499-1502?) que, a juicio de Canet, «imitan los de otra comedia ilustrada anterior, que en estos momentos desconocemos». Sus reflexiones advierten que Fadrique Biel solía copiar las estampas de otros libros del mercado editorial, principalmente salidos de las prensas de los hermanos Hurus en Zaragoza, pero también -en los últimos años de los 90- procedentes de Lyon y París. Su modus operandi era tallar de nuevo los grabados de forma directa sobre el ejemplar que imitaba y así, al no comprar las planchas xilográficas -y, además, ampliar la caja de impresión-, abarataba los costes de producción y de venta posterior. Esto lleva consigo la escasa originalidad de sus impresiones. Y «fue probablemente esta manera de trabajar en la primera época de la imprenta en la Península lo que motivó la petición insistente a los Reyes Católicos de Privilegios de impresión».

En un monográfico dedicado al libro medieval, era de obligada presencia un estudio que trazase el relevante papel del manuscrito en la narrativa contemporánea y a este propósito atiende Antonio Huertas Morales en «Manuscritos medievales en la novela española contemporánea». El recurso del manuscrito encontrado, aunque ya había sido utilizado en la novela histórica decimonónica, es Umberto Eco quien lo encumbra como protagonista absoluto en su Il nome della rosa. El libro antiguo se reviste en la novela actual de valor místico, mágico o esotérico erigiéndose en objeto de devoción, y no solo guarda secretos o revelaciones del pasado, sino que también funciona como puente entre la actualidad y el medievo. La presencia del manuscrito en la narrativa contemporánea y su amplio abanico de funciones son analizadas 
concienzudamente por el autor, quien distingue: «el manuscrito encontrado», tópico vinculado al género testimonial de las memorias, garantizando una historia íntima y auténtica en unos casos, y en otros sirve para encubrir una historia novelada en la que su protagonista es un mero cronista. No faltan ejemplos en los que se emplea este recurso para contradecir y refutar la verdad oficial o «como juego narrativo e historiográfico». En segundo lugar, «el manuscrito como guía», ya que atesora pistas o mapas secretos de los grandes tesoros medievales o, incluso, es el manual de iniciación que va dirigiendo las pruebas que legitimarán a los protagonistas para conocer o velar un oculto y transcendente secreto. Otro de sus empleos es como «portal a otro mundo», sobre todo en la novela fantástica y de ciencia ficción; el libro contendrá la «formula ritual o la ecuación matemática» para acceder a otras épocas y lugares. La cuarta función es la del «manuscrito espejo» de la acción de la novela y, por tanto, de la obra medieval. También desfilan por las páginas de la narrativa contemporánea manuscritos que aclaran los interrogantes autoriales y de composición de las grandes obras de la Edad Media, un buen ejemplo, que analiza Huertas Morales con detalle, es La Celestina. Asimismo, el hallazgo de un manuscrito puede ser el detonante de la acción y de un amplio abanico de peripecias. La «verdad incómoda» es otra de las funcionalidades del libro medieval, dado que los conocimientos o misterios que encierran podrían «socavar los misterios de la civilización». Y, por supuesto, no faltan novelas en las que el «manuscrito mágico» se proyecta hacia lo divino, diabólico o prodigioso.

En definitiva, como podrá comprobar el lector, se presenta un volumen sobre texto e imagen, texto como imagen e imagen como texto en el que se dan cita los trabajos de reconocidos especialistas a los que, como editora de este número de la Revista de poética medieval, quiero, como punto final a este preliminar, agradecer su disponibilidad y participación en este amplio, sugestivo y, a buen seguro, provechoso recorrido por Texto e ilustración en el libro medieval: factura física, lectura y recepción. 